\title{
Purification of the food-borne carcinogens 2-amino-3-methylimidazo [4,5-f]quinoline and 2-amino-3,8-dimethylimidazo[4,5-f $]$ quinoxaline in heated meat products by immunoaffinity chromatography
}

\author{
Robert J.Turesky, Christina M.Forster, \\ Hans Ulrich Aeschbacher, Hans Peter Würzner, \\ Paul L.Skipper ${ }^{1}$, Laura J.Trudel ${ }^{1}$ and \\ Steven R.Tannenbaum ${ }^{1,2}$ \\ Nestlé Research Centre, Nestec Ltd, Vers-chez-les-Blanc, 1000 Lausanne \\ 26, Switzerland and Massachuserts Institute of Technology, 'Toxicology \\ Program, Whitaker College of Health Sciences and Technology and \\ ${ }^{2}$ Department of Chemistry, 77 Massachusetts Avenue, Bldg 56, Room 311, \\ Cambridge, MA 02139, USA
}

$A$ rapid and simple scheme has been developed for the isolation and purification of two of the major mutagenic heterocyclic amines formed in heated beef products by affinity chromatography using monoclonal antibodies which recognize 2-amino-3-methylimidazo[4,5-f]quinoline (IQ). Two cell lines producing IgG antibodies were established following fusion of Sp2 or P3x.63 myeloma cells with spleen cells of immunized BALB/cby mice. The antigen was bovine gamma globulin haptenized with 2-(3-carboxypropylthio)-3-methylimidazo[4,5-f]quinoline. The antibodies were immobilized on CNBractivated Sepharose 4B. IQ and MeIQx formed in heated beef products were partially purified by XAD-2 chromatography and then applied to the affinity columns. Purification by affinity chromatography was adequate for subsequent quantitative analysis by HPLC with UV detection. With this purification scheme as little as $1 \mathrm{~g}$ of beef extract or $15 \mathrm{~g}$ of fried beef could be assayed for IQ and MeIQx at the part per billion level. Both antibodies had similar affinity constants for IQ $\left(9.3 \times 10^{6}\right.$ and $\left.6.7 \times 10^{6} \mathrm{M}^{-1}\right)$ and for MeIQx $\left(7.1 \times 10^{5}\right.$ and $\left.2.7 \times 10^{5} \mathrm{M}^{-1}\right)$ and both were suitable for immunoafinity purification of $\mathrm{IQ}$ from complex mixtures. MAb2 could be used as well to selectively remove MeIQx from meat products after partial purification by XAD-2. MAb1, despite having a 3-fold higher affinity than MAb2 for MeIQx, could not be used for affinity chromatography for this mutagen.

\section{Introduction}

The aminoimidazoquinolines and aminoimidazoquinoxalines are potent mutagens and rodent carcinogens $(1,2)$ which are formed in foods high in protein content, prepared under typical cooking practices $(3-9)$. Two of the more prominent compounds in this class of carcinogens are 2-amino-3-methylimidazo[4,5-f]quinoline (IQ*) and 2-amino-3,8-dimethylimidazo[4,5-f]quinoxaline (MeIQx). These compounds are generally present in the low parts per billion range. Early analytical procedures used to isolate and

Abbreviations: IQ, 2-amino-3-methylimidazo[4,5-f]quinoline; MeIQx, 2-amino-3,8-dimethylimidazo[4,5-f)quinoxaline; MS, mass spectrometry; MAb, monoclonal antibody; Glu-P-2, 2-aminodipyrido(1,2-a:3',2'-d)imidazole; 4,8-DiMeIQx, 2-amino-3,4,8-rimethylimidazo[4,5-f]quinoxaline; 7,8-DiMeIQx, 2-amino-3,7,8-trimethylimidazo[4,5-f]quinoxaline; DMF, $N, N$-dimethylformamide; BGG, bovine gamma globulin; BSA, bovine senum albumin; RIA, radioimmunoassay; PBS, phosphate buffered saline; PhIP, 2-amino-1-methyl-6phenylimidazo $4,5-b]$ pyridine. quantify these mutagens from cooked foods were laborious, time consuming and the estimates of heterocyclic amines content were based on highly purified fractions containing small percentages of the initial mutagenic activity. Thus, estimates were variable and it was not possible to accurately assess the amount of carcinogens consumed in the daily diet. More recently HPLC with electrochemical detection (9) or mass spectrometry $(10,11)$ has been used for quantitative analysis. While this has led to more accurate estimates of the heterocyclic amine content, there remains a need for more rapid sample preparation for the practical application of analyzing many samples.

Monoclonal antibodies (MAbs) which recognize small organic molecules such as carcinogens are a powerful tool for the rapid purification and quantification of these compounds from complex mixtures. Carcinogens for which MAbs have been raised include aflatoxin B1 (12), benzo[a]pyrene (13), 2-aminodi-

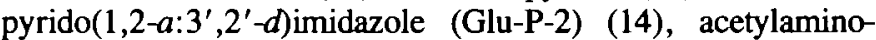
fluorene-DNA (15) and IQ $(16,17)$. In several instances, high affinity constants have made it possible to quantify carcinogens or their adduction products in complex mixtures with MAbs by means of competitive ELISA assays $(13,15,17)$. Quantification by ELISA may prove difficult in other cases if there are structurally related compounds present which cross react with the antibodies. Such a case has recently been demonstrated for antibodies raised against IQ and MeIQx (17).

Because of the high selectivity of MAbs it may be possible to utilize affinity chromatography as a means to simplify the purification procedures required for isolation and quantification of carcinogens in complex mixtures. Such an application of affinity chromatography has already been reported for the rapid purification of metabolites and nucleic acid adducts of aflatoxin in urine of humans (18). MAbs raised against IQ have already been successfully immobliized to CNBr-activated Sepharose 4B and been found to bind IQ which then could be quantitatively eluted (16). In this report we present a rapid purification scheme utilizing XAD-2 treatment followed by monoclonal antibody affinity chromatography to purify IQ and MeIQx from heated meat products.

\section{Materials and methods}

\section{Chemicals}

IQ, $\left[2-{ }^{14} \mathrm{C}\right] \mathrm{IQ}(11 \mathrm{mCi} / \mathrm{mmol}), \mathrm{MeIQx}$ and $\left[2-{ }^{14} \mathrm{C}\right] \mathrm{MeIQx}(13 \mathrm{mCi} / \mathrm{mmol})$ were purchased from Toronto Research Chemicals, Ontario, Cansda. 2-Amina-3,4,8trimethylimidazo[4,5-ffquinoxaline (4,8-DiMeIQx) and 2-amino-3,7,8-trimethylimidazo[4,5-f)quinoxaline (7,8-DiMeIQx) were symthesized as previously described (11). Bacterial-grade beef extract was purchased from Difco Laboratories, Detroit and food-grade beef extracts were purchased from several food suppliers. Analytical grade XAD-2 resin, particle size $0.3-1.0 \mathrm{~mm}$, was purchased from Serva Feinbiochemica, Heidelberg, FRG. CNBr-activated Sepharose 4B was purchased from Sigma Chemical Co., St Louis, USA. Dimilume-30 scintillation fluid was purchased from Packard Instruments Co., Zurich, Swizertand. All organic solvents were HPLC grade.

Synthesis of the hapten, 2-(3)-carbaxypropylthio-3-methylimidazo[4,5-f]quinoline

A freshly prepared solution of thiobutyrolactone (102 $\mathrm{mg}, 1 \mathrm{mmol})$ in water $(1.8 \mathrm{ml})$ containing $\mathrm{NaOH}(1 \mathrm{M})$ was added to a solution of 2-nitro-3-methyl- 
imidazo[4,5-flquinoline ( $9.5 \mathrm{mg}, 42 \mu \mathrm{mol}$ ) in $N, N$-dimethylformamide (DMF) $(0.8 \mathrm{ml})$ synthesized as previously described (19). After $3 \mathrm{~h}$ in a shaking water bath at $37^{\circ} \mathrm{C}$, the mixture was concentrated in vacuo and diluted with water $(10 \mathrm{ml})$. The aqueous solution was applied to one C-18 Sep-Pak (Waters Division of Millipore) and the eluent from that cartridge was applied to a second SepPak. Methanol eluents from both Sep-Paks were combined and evaporated to dryness, yielding $16 \mathrm{mg}$ of material. This was purified by chromatography on a Whatman Magnum-9 ODS-3 column eluted with a $\mathbf{4 0}$ min linear gradient of $10-100 \%$ methanol in water to yield $9 \mathrm{mg}(28 \mu \mathrm{mol})$ of the sodium salt of the hapten.

Coupling to bovine gamma glabulin (BGG) and serum albumin (BSA)

Isobutyl chloroformate $(3.5 \mu 1,27 \mu \mathrm{mol})$ was added to a solution of the above sodium salt $(27 \mu \mathrm{mol})$ in DMF $(400 \mu \mathrm{l})$ and held for $30 \mathrm{~min}$ at room temperature. One-half the mixture was then added to a solution of BGG $(15 \mathrm{mg})$ and the other half to a solution of BSA $(15 \mathrm{mg})$. Each protein was dissolved in $2 \mathrm{ml}$ sodium carbonate buffer $(100 \mathrm{mM}, \mathrm{pH} 9.4)$. After $2 \mathrm{~h}$ at $37^{\circ} \mathrm{C}$ in a shaking water bath, the reaction mixtures were dialyzed $24 \mathrm{~h}$ against two changes of phosphate buffer (100 mM, pH 7.3). After centrifugation of the BGG solution to remove some precipitate, the solutions were stored frozen. From specific activities of the solutions and protein concentrations determined by Lowry assay, it was calculated that the BGG and BSA had a hapten to protein ratio of 25:1 and 20:1 respectively.

Synthesis of the tracer, $N^{2}-\left(6-\left[{ }^{3} H\right.\right.$-acetamido $]-$

-hexyl)-3-methylimidazo[4,5-f]quinoline

2-Nitro-3-methylimidazo[4,5-f]quinoline $(9 \mathrm{mg})$ was dissolved in DMF (9 ml) containing $100 \mathrm{mg} / \mathrm{ml} 1,6$-hexanediamine. After $24 \mathrm{~h}$ in a shaking water bath at $37^{\circ} \mathrm{C}$, the mixture was concentrated in vacuo. The aqueous phase was evaporated to dryness with a rotary evaporator and the residue was dissolved in water (2 ml). The product was obtained by preparative chromatography (four runs) as described for the hapten, except that the mobile phase was buffered at pH 4.0 with $50 \mathrm{mM}$ ammonium formate. The combined fractions were evaporated to dryness and the residue was dissolved in $3 \% \mathrm{NH}_{4} \mathrm{OH}(1 \mathrm{ml})$ and the solution was applied to a C-18 Sep-Pak. The product was recovered by methanot elution after washing the carridge with water.

$\left[{ }^{3} \mathrm{H}\right]$ Sodium acetate $(3.4 \mathrm{Ci} / \mathrm{mmol}, 1.5 \mu \mathrm{mol})$ was obtained as a solution in ethanol $(0.5 \mathrm{ml})$ which was evaporated to dryness. The residue was suspended in DMF $(100 \mu)$, to which was added isobutyl chloroformate $(-0.25 \mu, 2 \mu \mathrm{mol})$. After $15 \mathrm{~min}$, the mixture was added to a solution of the above amine ( $2 \mu \mathrm{mol})$ in DMF $(100 \mu \mathrm{l})$. After $1 \mathrm{~h}$, the reaction was diluted with $10 \mathrm{ml}$ ammonum formate buffer ( $50 \mathrm{mM}, \mathrm{pH} 4.0$ ), and the resulting solution was applied to a $\mathrm{C}-18$ Sep-Pak. After washing with $12 \mathrm{ml}$ buffer the Sep-Pak was eluted with $3 \mathrm{ml}$ methanol. The residue was concentrated and then purified by thin-layer chromatography on Whatman $\mathrm{KC1} 18$ plates $(5 \times 20 \mathrm{~cm})$ developed in ammonium formate buffer ( $50 \mathrm{mM}, \mathrm{pH} 4.0$ ) containing $70 \%$ methanol. The yellow band at $R_{\mathrm{f}}=$ 0.5 was scraped off and eluted with methanol to yield $1 \mathrm{mCi}$ of product $(0.3 \mu \mathrm{mol}$, $\sim 20 \%$ yield).

\section{Preparation of antibodies}

Cell lines producing antibodies which recognize IQ were obtained from the fusion of spleen cells from immunized BALB/cby mice with either Sp2 or P3x.63 myeloma cells (20). Male and female BALB/By CJ mice (Jackson Laboratones), 16-18 weeks old were immunized with haptenized BGG in PBS emulsıfied with an equal volume of complete Freund's adjuvant (GIBCO). Two groups of five mice received either 50 of $100 \mu \mathrm{g}$ of antigen by i.p. injection of $0.2 \mathrm{ml}$ of emulsion. The mice were boosted as above with antigen in incomplete Freund's adjuvant, 12 days following the initial injection. Nine days later, samples were obtained by tail bleoding and the sera screened by ELISA for antibody titer. Three days prior to fusion, the mice received i.p. boosts of $100 \mu \mathrm{g}$ of antigen. Ascites was produced from hybridomas grown in CAF1 male mice which had been injected previously with $0.5 \mathrm{ml}$ pristane. The ascites fluids collected were pooled (5 mice/cell line) and used directly in the radioimmunoassay (RIA) or further purified by $40 \%$ saturated ammonium sulfate precipitation and dalysis against phosphate-buffered saline (PBS) at $4^{\circ} \mathrm{C}$.

\section{Immunaassays}

ELISA was used to determine antibody titer in mouse sera and hybridoma supernatants and was performed essentially as described previously (12) using haptenized BSA. Competitive RIA was used to determine affinity constants by a procedure already described elsewhere (12). The affinity constants of MAb1 for IQ and $\mathrm{MeIQx}$ were $9.3 \times 10^{6}$ and $7.1 \times 10^{5} \mathrm{M}^{-1}$ respectively, and the constants of $\mathrm{MAb2}$ were $6.7 \times 10^{6}$ and $2.7 \times 10^{5} \mathrm{M}^{-1}$.

Preparation of monoclonal antibaty affinity columns

Monoclonal antibody affinity columns were prepared as described by Groopman et al. (12) and Pharmacia (21). The MAbs were diluted in coupling buffer $(0.1 \mathrm{M}$ $\mathrm{NaHCO}_{3}, \mathrm{pH} 8.3 / 0.5 \mathrm{M} \mathrm{NaCl}$ ) and coupled to CNBr-activated Sepharose 4B which had been swelled in $1 \mathrm{mM} \mathrm{HCl}$. Coupling was performed with $2 \mathrm{mg}$ protein/1 ml gel with a final protein concentration in the reaction medium at
$0.5 \mathrm{mg} / \mathrm{ml}$. Unbound sites of the antibody-bound gel were blocked with $0.2 \mathrm{M}$ Tris- $\mathrm{HCl}$, pH 8.0.

\section{Purification of $I Q$ and MelQx from beef extracts}

Ten grams of beef extract were diluted with $20 \mathrm{ml}$ of distilled water and added to $60 \mathrm{ml}$ of methanol which was continuously stirring. The samples were then centrifuged at $10000 \mathrm{~g}$ for $10 \mathrm{~min}$ to remove the precipitated protein. The precipitate was resuspended in $20 \mathrm{ml}$ of distilled water and added to another $60 \mathrm{ml}$ of methanol. The preciptated proteins were once again removed by centrifugation. The superantants were pooled and concentrated by rotary evaporation at $37^{\circ} \mathrm{C}$ to a vohume of $\sim 20 \mathrm{ml}$. The supermatants were basified with $1 \mathrm{~N} \mathrm{NaOH}$ to $\mathrm{pH} 8.5$ and adsorbed to $7 \mathrm{~g}$ of XAD-2 resin which had been prewashed in sequence with acetone, methanol, water and placed into a glass column $(15 \times 1.5 \mathrm{~cm}$ i.d.) $(7,11)$. The top of the column was packed with a small plug of glass wool to stabilize the resin. The beef solution was passed through the column at a flow rate of $2 \mathrm{ml} / \mathrm{min}$ and the resin was then washed with $70 \mathrm{ml}$ of distilled water. The heterocyclic amines were eluted from the resin by successive washes of $70 \mathrm{ml}$ of acetone followed by $70 \mathrm{ml}$ of methanol.

These two organic eluents were pooled and rotary evaporated to dryness. The samples were then resuspended in $10 \mathrm{ml}$ of PBS so that the concentration of the extract was $1 \mathrm{~g}$ equivalent starting material/ml. The extract was applied to the antibody which had been immobilized to $\mathrm{CNBr}$-activated Sepharose 4B. One gram equivalent of extract was added to $1.2 \mathrm{ml}$ of gel (for MAb1) or $2.0 \mathrm{ml}$ of gel (for MAb2) which had been loaded into a glass column $(15 \times 0.5 \mathrm{~cm}$ i.d.). The extract was passed through the affinity column at a flow rate of $1.5 \mathrm{ml} / \mathrm{min}$ with the aid of a peristaltic pump and then the column was washed with 10 bed volumes of PBS followed by 10 volumes of water. IQ and MeIQx were eluted by washing the affinity column with 10 volumes of methanol. The pooled aqueous fractions and the methanol fraction were rotary evaporated to dryness.

Preparation of fred beef

Fresh chopped beef was purchased at a local supernarket and 100-g batches were molded into patties $(8-10 \mathrm{~cm}$ in diameter, $1.5-1.8 \mathrm{~cm}$ in thickness). The patties were heated for 5 or $10 \mathrm{~min}$ on a commercially available two-sided fryer which contained a heating element on both surfaces. The initial temperature of the heating surface was $250^{\circ} \mathrm{C}$. After cooking, the patties were chopped and then homogentzed for $5 \mathrm{~min}$ in $250 \mathrm{ml}$ of distilled water using a Waring blender. One hundred gram equivalents of starting material were added to 2 volumes of methanol in order to precipitate protein. After standing for $15 \mathrm{~min}$ the proten was removed by centrifugation at $5000 \mathrm{~g}$ for $10 \mathrm{~min}$. The pellet was resuspended in $100 \mathrm{ml}$ of distilled water and the protein was precipitated a second time with 2 volumes of methanol. IQ and MeIQx were isolated as described above except that 16.5 gram equivalents of fried beef were applied to $1.0 \mathrm{ml}$ of affinity gel.

Chemical analysis

IQ and MeIQx were quantified by HPLC using the Hewlett-Packard 1090M system. Samples were analyzed wtih a Supelco LC-CN (Cyano) column (5 $\mu \mathrm{m}$ particle size, $4.6 \mathrm{~mm}$ i.d. $\times 25 \mathrm{~cm}$ in legnth) using $75 \% 0.15 \mathrm{M}$ ammonium acetate $\mathrm{pH} 7.5$ and $25 \%$ acetonitrle:methanol (4:1) at a flow rate of $1.5 \mathrm{ml} / \mathrm{min}$. In some instances a second chromatographic condition was employed which consisted of $83 \% 0.10 \mathrm{M}$ ammonium acetate $\mathrm{pH} 7.6$ containing $5 \%$ methanol and $17 \%$ acetonutrle:methanol $(4: 1)$ at a flow rate of $1.5 \mathrm{ml} / \mathrm{min}$. Absorbance was measured at $264 \mathrm{~nm}$ (IQ) and at $274 \mathrm{~nm}$ (MelQx).

\section{Mutation assays}

The Ames reversion assay was used to measure mutagenic activity by the standard plate test using Salmonella typhimurium strain TA98 with metabolic activation (22). Liver S-9 obtained from male Sprague-Dawley rats induced with Aroclor-1254 was used for metabolic activation of meat extracts at a 10\% S-9 concentration which was equivalent to $1.5 \mathrm{mg}$ protein/plate. Linear regression analysis was performed using the least squares method over the non-toxic portion of the dose response curve by the method of Bernstein et al. (23). Each assay was performed using five data points with three plates per point. The spontaneous revertant rate was 45-60 colonies/plate.

\section{Recovery experiments}

Radiolabeled IQ or MeIQx was added to meat products in order to determine the extraction efficiency. The compounds were added to bacterial- or food-grade beef extract at the levels of both 50 and $5 \mathrm{ng} / \mathrm{g}$ after the extracts had been dissolved in water. The amines also were added to fried beef at a concentration of $5 \mathrm{ng} / \mathrm{g}$ during the homogenization of the meat. Radioactivity was measured by liquid scintillation counting using an LKB 1217 counter.

\section{Results}

A partial purification of IQ and MeIQx from heated meat products was required prior to application of affinity chromatography. Protein precipitation followed by XAD- 2 treatment, which is a 
Table I. Percent recovery of ${ }^{14} \mathrm{C}$-labeled IQ and MeIQx from heated beef products

\begin{tabular}{llrrrrr}
\hline & & \multicolumn{2}{c}{ Bacterial-grade beef } & & \multicolumn{2}{c}{ Fried beef } \\
\cline { 7 - 8 } & & \multicolumn{1}{c}{ IQ } & MeIQx & & IQ & MeIQx \\
\hline XAD-2 & Organic phase & 83.4 & 83.3 & & 81.5 & 75.1 \\
MAb1 & Aqueous phase & 0.8 & 79.8 & & Not tested \\
& Organic phase & 75.5 & 1.3 & & \\
MAb2 & Aqueous phase & 0.0 & 6.1 & & 0.0 & 0.0 \\
& Organic phase & 83.4 & 77.6 & & 81.5 & 75.1 \\
\hline
\end{tabular}

Bacterial-grade beef extract was spiked with IQ or MeIQx at a concentration of $50 \mathrm{ng} / \mathrm{g}$ and fried beef was spiked with the mutagens at a concentration of $5 \mathrm{ng} / \mathrm{g}$. Average of two experiments. Values differed from each other by $<5 \%$. One gram equivalent of bacterial grade beef extract was applied to $1.2 \mathrm{ml}$ of MAbl or $2.0 \mathrm{ml}$ of MAb2; 16.5 gram equivalents of fried beef heated for $10 \mathrm{~min}$ at $250^{\circ} \mathrm{C}$ was added to $1.0 \mathrm{ml}$ of MAb2.
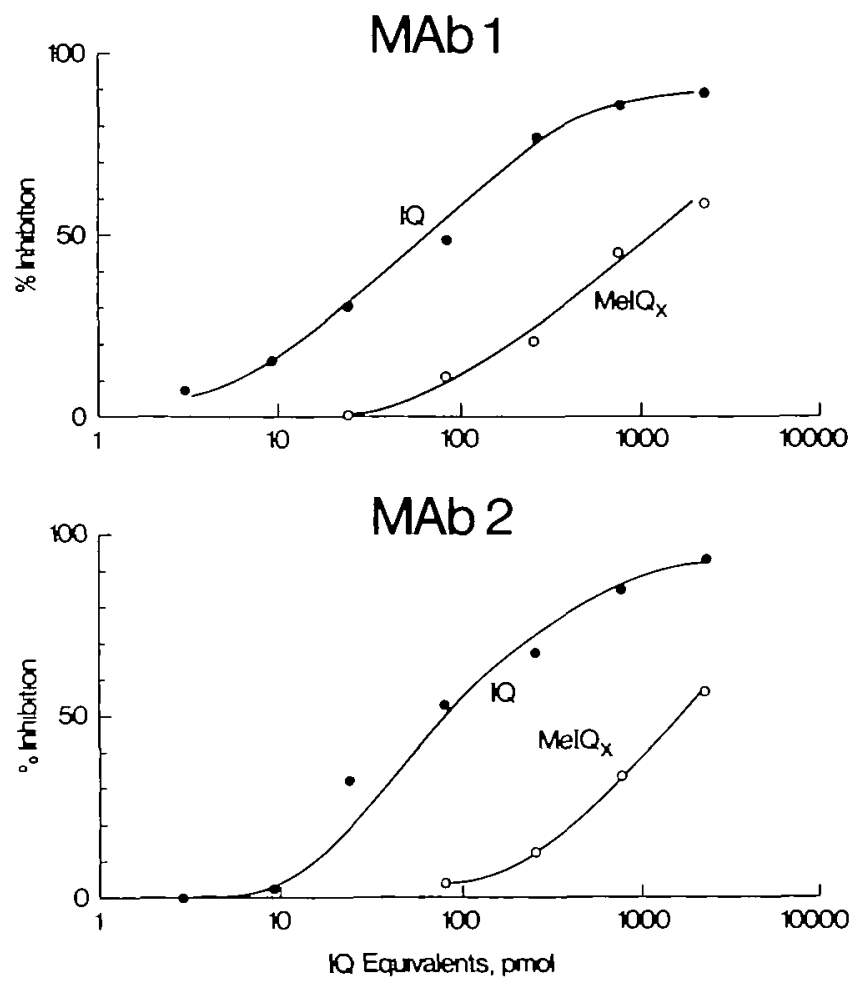

Fig. 1. Competitive RIA data for IQ $(\bullet)$ and MeIQx $(O)$ with MAb1 and MAb2.

rapid fractionation procedure, achieves an adequate degree of purification of these heterocyclic amines for affinity chromatography. Samples purified by XAD-2 chromatography were found to be more suitable than samples purified by blue cotton (24) for affinity chromatography because a larger initial sample of beef extract or fried beef could be applied. XAD-2 treatment was also superior to an acid/base partitioning because the recovery of radiolabeled IQ or MeIQx by XAD-2 treatment was higher and more reproducible (our unpublished observations). As is shown in Table I, radioactive IQ and MeIQx were recovered from fried beef and beef extracts in $\sim 80 \%$ yield in the organic eluents of the XAD-2 resin. The XAD-2 organic eluent from beef extracts then were applied, after reconstitution in PBS, to MAb1 affinity column. When the eluents were spiked with $\left[{ }^{14} \mathrm{C}\right] \mathrm{QQ}$ it was observed that the binding capacity of the

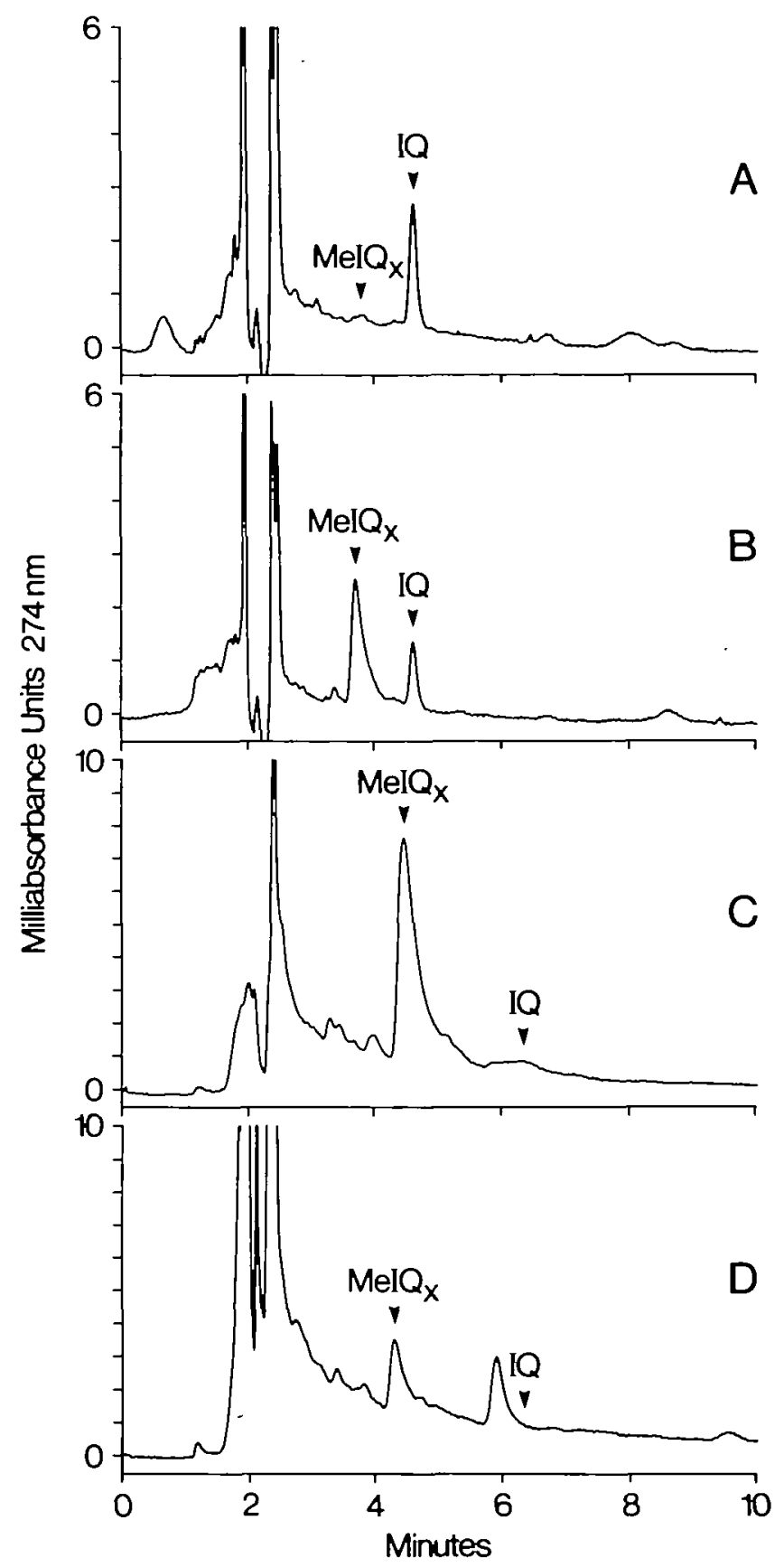

Fig. 2. HPLC of immunopurified mutagens from heated meat products: (a) $0.6 \mathrm{~g}$ equivalents of bacterial-grade beef extract purified by MAb1; (b) $0.3 \mathrm{~g}$ equivalents of bacterial-grade beef extract purified by MAb2; (c) $0.6 \mathrm{~g}$ equivalents of food-grade beef extract purified by MAb2; (d) $20 \mathrm{~g}$ equivalents of fried beef heated for $5 \mathrm{~min}$ at $250^{\circ} \mathrm{C}$ which had been purified by MAb2. Chromatograms (a) and (b) were performed under the first set of HPLC condittons described in Materials and methods, while (c) and (d) were performed under the second set of conditions.

affinity gel was decreased to $\sim 10 \%$ of the binding capacity obtained from the chemically pure standard compound. Approximately $100 \mathrm{ng}$ of IQ [50 ng of ${ }^{14} \mathrm{C}$-labeled compound plus $50 \mathrm{ng}$ of IQ and $50 \mathrm{ng}$ of MeIQx produced in the extract (9)] contained in $1 \mathrm{~g}$ equivalent of bacterial grade beef extract could bind to $1.2 \mathrm{ml}$ of affinity gel MAb1 while $1 \mu \mathrm{g}$ of pure IQ could be bound to the gel (MAb1). Under these conditions $\sim 1 \%$ of the radioactive IQ in beef extract which was applied to the column was recovered in the aqueous eluents while the radioactivity 
bound to the antibody was recovered in the methanol eluents at values which averaged $90 \%$ (Table $\mathrm{D}$. $\left[{ }^{14} \mathrm{C}\right] \mathrm{MeIQx}$ that had been added to beef extract was not antigenically bound when the antibody was attached to the resin and virtually all of the radioactivity was recovered in the aqueous eluent. Also the affinity column had an extremely low binding capacity for synthetic MeIQx. Similar results were obtained for MAb1 using food-grade beef extract spiked with $\left[{ }^{14} \mathrm{C}\right] \mathrm{IQ}$ or MeIQx at a level of $5 \mathrm{ng} / \mathrm{g}$. MeIQx was bound by the second lot of antibody, MAb2, where $\sim 93 \%$ of the radioactive MeIQx was recovered in the methanol eluent. Up to $16.5 \mathrm{~g}$ equivalents of fried beef which had been spiked with ${ }^{14} \mathrm{C}$-labeled IQ or MeIQx at a level of $5 \mathrm{ng} / \mathrm{g}$ could bind to $1.0 \mathrm{ml}$ of MAb2 affinity resin.

Thus, despite the diminished binding capacity of these MAbs for IQ and MeIQx in complex mixtures, a high level of these amines could still be bound to the affinity columns for practical purposes. It was observed that neither the 4,8-DiMeIQx or 7,8-DiMeIQx homologues, even when tested as pure standards, bound to the MAb affinity columns.

The competition curves of the competitive RIAs are illustrated in Figure 1. The curves are quite similar in shape for both IQ and MeIQx with affinity constants of MAb1 for IQ and MeIQx at values of $9.3 \times 10^{6}$ and $7.1 \times 10^{5} \mathrm{M}^{-1}$ respectively, and affinity constants for MAb2 at values of $6.7 \times 10^{6}$ and $2.7 \times 10^{5} \mathrm{M}^{-1}$. It was surprising that MAb2, the monoclonal antibody with the weaker affinity constant for MeIQx, could be used successfully in affinity chromatography to purify this compound from complex mixtures while MAb1 could not.

Because of the high extinction coefficients of IQ and MeIQx as little as $1 \mathrm{ng}$ of each compound could be detected by HPLC by monitoring the absorbance of the eluent. The calibration curve was found to be linear from 1 to $50 \mathrm{ng} /$ injection for each compound. IQ was readily detected in bacterial-grade beef extract which had been purified by MAb1 and the chromatogram of immunopurified IQ is shown in Figure 2A. In contrast, MeIQx was not, which is consistent with the radioactive-binding data of MAbl (Table $\mathrm{I}$ ). The chromatogram of bacterial-grade extract purified with lot MAb2 which recognizes both MeIQx and IQ, shown in Figure 2B, contains both mutagens. Food-grade beef extracts were also analyzed for IQ and MeIQx using both antibodies. The chromatogram produced by extracts purified by MAb2 is shown in Figure 2C. MeIQx was readily detected while there were only trace amounts of IQ. Mutagenic components purified from fried beef heated for 5 min with MAb2 is shown in Figure 2D. MeIQx was readily detected while IQ was not. UV spectra for IQ and MeIQx obtained from beef extracts and MeIQx recovered from fried beef were recorded as these compounds eluted. The peaks were pure judging from these spectra and were identical to the spectra of authentic materials, indicating that the peak areas accurately reflected the amount of mutagens present.

It should be noted that a prominent peak which eluted at $5.9 \mathrm{~min}$ in the chromatogram of fried beef (Figure 2D) appears to have been recognized by the antibody, suggesting the compound had a structural feature in common to IQ and MeIQx. The formation of this compound also was found to increase with time of cooking. The UV spectrum of this substance, however, was vastly different from those of IQ, MeIQx or another foodborne mutagen previously identified in fried beef which contains an aminoimidazole moiety, 2-amino-1-methyl-6-phenylimidazo [4,5-f]pyridine (PhIP) (25). Unfortunately, because of the low amount of product isolated, it was not possible to assay the compound for mutagenicity.

Quantitative estimates of IQ and MeIQx in beef extracts and fried beef are presented in Table II along with predictions of the mutagenic activity in the extract attributable to these two mutagens as well as the observed fractionation of mutagenic activity. Mutagenic activity was recovered from the aqueous and organic eluents of the affinity column in values which ranged between 80 and $115 \%$ of the applied activity, assuming mutagenicity is additive in nature. The amounts of IQ and MeIQx determined by HPLC have nearly the same mutagenic activity as was observed in the methanol eluents of the affinity columns. Since both MeIQx and IQ were recognized by MAb2 while only IQ was recognized by $\mathrm{MAbl}$, an estimate of the contribution of MeIQx to the total mutagenicity in the XAD-2 residues can be determined by taking the difference in activity from the methanol eluents from the two affinity columns. The chemical analysis

Table II. Fractionation of mutagenic activity in beef extracts and fried beef by monoclonal antibody affinity chromatography and relationship to the mutagenicity and amounts of IQ and MeIQx determined by quantitative chemical analysis

\begin{tabular}{|c|c|c|c|c|c|c|c|c|c|}
\hline \multirow[t]{3}{*}{ Sample } & \multicolumn{9}{|l|}{ Mutagenic activity ${ }^{1}$} \\
\hline & \multirow[t]{2}{*}{ Bound to XAD-2 } & \multicolumn{3}{|c|}{ From immunoaffinity column } & \multicolumn{5}{|c|}{ Calculated for IQ and MeIQx in the bound fraction ${ }^{2}$} \\
\hline & & & Not bound & bound & IQ & $(\mathrm{ng} / \mathrm{g})$ & MeIQx & $(\mathrm{ng} / \mathrm{g})$ & Total \\
\hline Bacterial-grade extract & 35100 & $\begin{array}{l}\text { MAb1 } \\
\text { MAb2 }\end{array}$ & $\begin{array}{l}16200 \\
13800\end{array}$ & $\begin{array}{l}18100 \\
23600\end{array}$ & $\begin{array}{l}14500 \\
14200\end{array}$ & $\begin{array}{l}(49 \pm 2.0) \\
(48,48)\end{array}$ & $\begin{array}{l}\text { n.d. } \\
5340\end{array}$ & $(54,58)$ & $\begin{array}{l}14500 \\
19540\end{array}$ \\
\hline Food-grade extract 1 & 10600 & $\begin{array}{l}\text { MAb1 } \\
\text { MAb2 }\end{array}$ & $\begin{array}{l}6740 \\
4690\end{array}$ & $\begin{array}{l}2190 \\
4200\end{array}$ & $\begin{array}{l}1840 \\
1480\end{array}$ & $\begin{array}{l}(6.2 \pm 2.0) \\
(5.2,4.8)\end{array}$ & $\begin{array}{l}\text { n.d. } \\
2910\end{array}$ & $(31,30)$ & $\begin{array}{l}1840 \\
4390\end{array}$ \\
\hline Food-grade extract 2 & 15000 & $\begin{array}{l}\text { MAb1 } \\
\text { MAb2 }\end{array}$ & $\begin{array}{r}11900 \\
5760\end{array}$ & $\begin{array}{l}1010 \\
6420\end{array}$ & $\begin{array}{l}\text { n.d. } \\
\text { n.d. }\end{array}$ & & $\begin{array}{l}\text { n.d. } \\
6580\end{array}$ & $(69 \pm 13)$ & $\begin{array}{r}0 \\
6580\end{array}$ \\
\hline Food-grade extract 3 & 5960 & $\begin{array}{l}\text { MAb1 } \\
\text { MAb2 }\end{array}$ & $\begin{array}{l}4740 \\
2440\end{array}$ & $\begin{array}{r}480 \\
2930\end{array}$ & $\begin{array}{l}\text { n.d. } \\
\text { n.d. }\end{array}$ & & $\begin{array}{l}\text { n.d. } \\
2240\end{array}$ & $(23,24)$ & $\begin{array}{r}0 \\
2240\end{array}$ \\
\hline Beef patties fried $5 \mathrm{~min}$ & 170 & MAb2 & 90 & 50 & n.d. & & 60 & $(0.5,0.8)$ & 60 \\
\hline Beef patties fried $10 \mathrm{~min}$ & 910 & MAb2 & 700 & 120 & n.d. & & 130 & $(1.3,1.5)$ & 130 \\
\hline
\end{tabular}

n.d. = not detected.

'Revertants/g equivalent activity was determined using non-toxic concentrations in the linear range of the dose-response curve.

${ }^{2}$ Calculation based on specific activities of 296000 and 95400 revertants/ $\mu 8$ for IQ and MeIQx respectively. The values in parentheses are amounts of IQ and MeIQx present in the bound fractions ( $\mathrm{ng} / \mathrm{g}$ equivalent) determined by HPLC as described in Materials and methods. Two or three determinations \pm SD were made for each sample. 
demonstrates that MeIQx is present in greater amounts than is $\mathrm{IQ}$ in all of the heated beef products.

MeIQx was also a prominent mutagen formed in fried beef, although it represented a smaller contribution to the total mutagenicity than that which was observed in beef extracts (Table II). Increased cooking time led to an increase in mutagen formation and increased amounts of MeIQx which is in agreement with previous studies $(7,11,26)$. Under these assay conditions IQ was not detected. The lower limit of detection of IQ by HPLC was $\sim 1 \mathrm{ng}$. Therefore, if IQ was present, it was present at the order of $<0.1$ p.p.b. since 15 or $20 \mathrm{~g}$ equivalents of fried beef were analyzed by HPLC. Other mutagenic components in addition to IQ and MeIQx which were bound to $\mathrm{XAD}-2$ but not recognized by either MAb1 or MAb2 are present in meat extracts and fried beef (Table II). A portion of this mutagenic activity is attributed to 4,8-DiMeIQx $(7,11,26-28)$, PhIP (25), as well as other mutagens which have remained unidentified (7).

\section{Discussion}

The low levels of heterocyclic amines such as IQ and MeIQx in cooked foods and their close similarity in chemical structure to other compounds present have made it extremely challenging for analytical chemists to develop facile purification schemes and methods of detection. In the last several years great improvements in isolation schemes have been developed $(7-11,24)$. HPLC in combination with MS is perhaps the most specific method of detection and requires the least amount of sample purification prior to chemical analysis $(10,11)$. Also products analyzed by gas chromatography using electron capture negative ion chemical ionization MS have been shown to require minimal sample preparation, although chemical derivatization is required prior to chemical analysis (28). With this method, MeIQx and 4,8-DiMeIQx were quantified in fried beef at the very low parts per billion level. The use of MAbs in the form of affinity chromatography is an even greater improvement over these techniques currently used for the isolation and quantification of IQ and MeIQx (4-11) and the immunopurified amines can be analyzed directly by HPLC. Only a few grams of product are required for analysis. The isolation scheme is extremely rapid, requiring simple protein precipitation and XAD-2 adsorption prior to affinity chromatography. Thus, because of the minimal sample preparation, many products can be processed quickly for quantitative analysis.

An altemative method of analysis which has been used for estimation of heterocyclic amines in cooked beef products with MAbs is competitive ELISA (17). These immunoassays, however, suffer from a lack of specificity. Structurally related compounds which could cross react with the antibodies and prevent accurate estimates of amine content may be present in cooked beef. In fact, such an example of compounds formed in fried beef has recently been reported (29). Chemical analysis of immunopurified amines avoids this problem of cross reactivity. The limit of detection of synthetic IQ and MeIQx by HPLC with an UV detector under the chromatographic conditions used in this study is $\sim 1.0 \mathrm{ng}$. This sensitivity is decreased marginally when analyzing complex mixtures such as cooked beef products and $\sim 2$ ng of amine must be injected for reliable quantitation. We have been able to measure the content of IQ and MeIQx at a part per billion level in as little as $1 \mathrm{~g}$ of beef extract or $15 \mathrm{~g}$ of fried beef prepared under typical household conditions. In all samples tested, MeIQx was the principal mutagen formed. The lower limit of detection obtained by this chemical analysis is comparable to the sensitivity limits obtained by competitive ELISA of heated meat products (17).

Interestingly, MAbl, despite a 3-fold higher affinity constant than MAb2 for MeIQx, could not be used for affinity chromatography of this compound. Thus, immobilization of an antibody to a solid support resin can alter the antibody's ability to recognize the antigen, perhaps through changes in tertiary structure. Therefore, antibodies with higher affinity constants may not be the best candidates for application in immunoaffinity chromatography and RIA-generated affinity constants are not necessarily a good predictor for selection. Immobilized antibodies must be carefully characterized for their selectivity pattern of binding pure chemicals. Furthermore, the binding efficiency of the antibody for the antigen in a complex mixture may be reduced and must be determined prior to quantitative analyses.

The application of immunoaffinity chromatography has enabled us to quantify the amount of the heterocyclic amines IQ and MeIQx in heated meat products on a micro scale level with a high degree of sensitivity and excellent reproducibility. Our estimates of these compounds formed in beef extracts and fried beef concur with values reported by other investigators who used methods far more laborious for isolation and quantification $(4-7,9-11,26-28)$. With only minor modifications in the isolation procedure, affinity chromatography could be applied to isolate these mutagens from a variety of cooked foods and provide quantitative data to assess the health risk of these potential carcinogens to humans.

\section{Acknowledgements}

The authors would like to thank C.Julmi and U.Wolleb from Genetic Toxicology, Nestle Research Centre for performing mutation assays. This investigation was supported by a PHS grant no. ESO0597, awarded by the National Institutes of Environmental Health Services.

\section{References}

1. Sugimura,T. (1985) Carcinogencity of mutagen heterocyclic amines formed during cooking process. Mutat. Res., 150, 33-41.

2. Kato, T., Ohgaki,H., Hasegawa,H., Sato,S., Takayama,S. and Sugimura,T. (1988) Carcinogenicity in rats of a mutagenic compound, 2-amino-3,8-di-

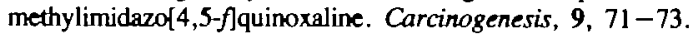

3. Sugimura,T. and Sato,S. (1983) Mutagens - carcinogens in foods. Cancer Res., Suppl. 43, 2415-2421.

4. Kasai,H., Yamaizumi,Z., Shiomı,T., Yokayama,S., Mryazawa,T., Wakabayshi,K., Nagao,M., Sugimura,T. and Nishimura,S. (1981) Structure of a potent mutagen isolated from fried beef. Chem. Lett., 112, 485-488.

5. Hargraves, W.A. and Pariza,M.W. (1983) Purification and mass spectral characterization of bacterial mutagens from commercial beef extract. Cancer Res., 43, 1467-1472.

6. Turesky,R.J., Wishnok,J.S., Tannenbaum,S.R., Pfund,R.A. and Buchi,G.H. (1983) Qualitative and quantitative characterization of mutagens in commercial beef extract. Carcinogenesis, 4, 863-866.

7. Felton,J.S., Knize,M.G., Wood,C., Wuebbles,B.J., Healey,S.K., Steurmer,D.H., Bjeldanes,L.F., Kimbles, B.J. and Hatch,F.T. (1984) Isolation and characterization of new mutagens from fried ground boef. Carcinogenesis, $5,95-102$.

8. Kikugawa,K. and Kato,T. (1987) Formation of mutagens, 2-amino-3,8-dimethylimidazo[4,5-f]quinoxaline (MeIQx) and 2-amino-3,4,8-trimethylimidazo[4,5-f]quinoxaline (4,8-DiMeIQx) in heated fish meats. Mutat. Res., $179,5-14$.

9. Takashashi,M., Wakabayashi,K., Nagao,M., Yamamoto,M., Masui,T., Goto,T., Kinae,N., Tomita,I. and Sugimura,T. (1985) Quantification of 2-amino-3-methylimidazo[4,5-f)quinoline (IQ) and 2-amino-3,8-dimethylimidazof 4,5-ffquinoxaline (MeIQx) in beef extracts by liquid chromatography with electrochemical detection (LCEC). Cancinogenesis, 6, 1195-1199.

10. Yamaizumi,Z., Kasai,H., Nishimura,S., Edmonds,C.G. and McCloskey.J.A. (1986) Stable isotope dilution quantification of mutagens in cooked foods by combined liquid chromatography - thermospray mass spectrometry. Mutat. Res., 173, $1-7$.

11. Turesky,R.J., Bur,H., Huynh-Ba,T., Aesctbacther,H.U. and Milon,H. (1988) Analysis of mutagenic heterocyclic amines in cooked beef products by high 


\section{R.J.Turesky et al.}

performance liquid chromatography in combination with mass spectrometry. Food Chem. Toxicol., 26, 501-509.

12. Groopman,J.D., Trudel,L.J., Donahue,P.R., Marshak-Rothstein,A. and Wogan,G.N. (1984) High-affinity monoclortal antibodies for aflatoxins and their application to solid-phase immunoasays. Proc. Natl. Acad. Sci. USA, 81, 7728-7731.

13. Hsu,I.-C., Poirier,M.C,. Yuspa,S.H., Grunberger,D., Weinstein,I.B., Yolken,R.H. and Harris,C.C. (1981) Measurement of benzo[ $a]$ pyrene:DNA adducts by enzyme immunoasays and radıoimmunoassay. Cancer Res. , 41, $1091-1095$.

14. Heber,E., Saint-Ruf,G. and Leng,M. (1985) Immunological titration of 3-N-acetylhydroxyamino-4,6-dimethyldipyrido $\left(1,2-a: 3^{\prime}, 2^{\prime}-d\right)$ imidazole rat liver DNA adducts. Carcinogenesis, 6, 937-939.

15. Hsu, I.C., Poirier, M.C., Yuspa,S.H,. Yolken, R.H. and Harris,C.C. (1980) Ultrasensitive enzymatic radioimmunoassay (USERLA) detects femtomoles of acetylaminofluorene-DNA adducts. Carcinogenesis, 1, 455-458.

16. Skıpper,P.L., Trudel,L.J., Tannenbaum,S.R. and Wogan,G.N. (1987) Monoclonal antibodies recognizing 2-amino-3-methylimidazo[4,5-f]quiroline (IQ). Proc. Am. Assoc. Cancer Res., 28, 128.

17. Vanderlaan,M., Watkins, B.E., Hwang,M., Knize,M.G. and Felton,J.S. (1988) Monoclonal antibodies for the immunoassay of mutagenic compounds produced by cooking beef. Carcinagenesis, 9, 153-160.

18. Groopman,J.D., Donahue,P.R., Zhu,J., Chen,J. and Wogan,G.N. (1985) Aflatoxin metabolism in humans: detection of metabolites and nucleic acid adducts in urine by affinity chromatography. Proc. Natl. Acad. Sci. USA, $82,6492-6496$.

19. Turesky,R.J., Skupper,P.L. and Tannenbaum,S.R. (1987) Binding of 2-amino-3-methylimidazo[4,5-f]quinoline to hemoglobin and albumin in viwo in the rat. Identification of an adduct suitable for dosimetry. Carcinogenesis, 8, $1537-1542$.

20. Marshak-Rothestein,A., Fink,P., Gridley,T., Raulet,D.H., Bevan,M.J. and Gefter,M.L. (1979) Properties and applications of monoclonal antibodies directed against determinants of the Thy-1 locus. J. Immunol., 122, $2491-2497$

21. Pharmacia Fine Chemicals (1979) Affinity Chromatography, Principles and Methods.

22. Maron,D.M. and Ames,B.N. (1983) Revised methods for the Salmonella mutagenicity test. Mutat. Res., 113, 173-215.

23. Bernstein,L., Kaldor,J., McCann,J. and Pike,M.C. (1982) An empirical appraach to the statistical analysis of mutagenesis data from Salmonella test. Mutat. Res., 97, 267-281.

24. Hyatsu,H., Oka,T., Wakata,A., Ohara,Y., Hyatsu,T., Kobayashi,H. and Arimoto,S. (1983) Adsorption of mutagens to cotton bearing covalently bound trisulfo-copper-phthalocyanine. Mutat. Res., 119, 233-238.

25. Felton,J.S., Knize,M.G., Shen,N.H., Lewis,P.R., Andresen,B.D., Happe,J. and Hatch,F.T. (1986) The isolation and identification of a new mutagen from friad ground beef: 2-amino-1-methyl-6-phenylimidazo[4,5-f]pyridine (Ph,P) Carcinogenesis, 7, 1081-1086.

26. Knize,M.G., Andresen,B.D., Healy,S.K., Shen,N.H., Lewis,P.R., Bjeldanes,L.F., Hatch,F.T. and Felton,J.S. (1985) Effects of temperature, patty thrckness and fat content on the production of mutagens in fried ground beef. Food Chem. Taxicol., 23, 1035-1040.

27. Takahashi,M., Wakabayashi,K., Nagao,M., Yamaizumi,Z., Sato,S., Kinae,N., Tomita,I. and Sugimura,T. (1985) Identification and quantification of 2-amino-3,4,8-trimethylimidazo[4,5-f]quinoxaline (4,8-DiMeIQx) in beef extract. Carcinogenesis, 6, 1537-1539.

28. Murray,S., Goodertam,N.J., Boobis,A.R. and Davies,D.S. (1988) Measurement of MeIQx and DiMeIQx in fried beef by capillary column gas chromatography electron capture negative ion chemical ionisation mass spectrometry. Carcinogenesis, 9, 321-325.

29. Felton,J.S., Watkins, B.E., Hwang,M., Knize,M.C. and Vanderlaan,M. (1988) Immunoassay of mutagenic/carcinogenic heterocyclic amines produced by cooking foods. Proc. Am. Assoc. Cancer Res., 29, 90.

Received on July 13, 1988; revised on September 21, 1988; accepted on September 26,1988 